UDC 621.391

\title{
FEASIBILITY REASONING OF CREATING ULTRA-LOW ORBIT COMMUNICATION SYSTEMS BASED ON SMALL SATELLITES AND METHOD OF THEIR ORBITS DESIGNING
}

\author{
${ }^{1}$ Olexandr I. Lysenko, ${ }^{2}$ Miroslav K. Sparavalo, ${ }^{4}$ Olena M. Tachinina, \\ ${ }^{1}$ Valerii S. Yavisya, ${ }^{3}$ Sergiy O. Ponomarenko \\ ${ }^{1}$ Institute of Telecommunication Systems \\ Igor Sikorsky Kyiv Polytechnic Institute, Kyiv, Ukraine \\ ${ }^{2}$ Institute of Telecommunication Systems \\ Igor Sikorsky Kyiv Polytechnic Institute, New York, USA \\ ${ }^{3}$ Institute of Aerospace Technologies \\ Igor Sikorsky Kyiv Polytechnic Institute, Kyiv, Ukraine \\ ${ }^{4}$ Aerospace faculty \\ National Aviation University, Kyiv, Ukraine
}

\begin{abstract}
Background. The article is devoted to the substantiation of the approach to solving the global problem for mankind: the creation of satellite communications technology that does not pollute space with debris. Ultra-low-orbit satellite communication systems (ULO SCS) are communication systems with cluster (distributed) satellites that form a grouping (armada) of small, ultra-small, nano-, pico-satellites that move in orbits close to the dense layers of the Earth's atmosphere (sliding on the upper edge of the dense layer of the Earth's atmosphere - a sliding orbit). The motion in such orbit of a small-sized apparatus (provided that the engine is not started) leads to its rapid deceleration and complete combustion in the Earth's atmosphere, i.e. complete orbit purification from space debris.

Objective. To justify the feasibility and the possibility of creating and maintaining the functioning of an economical, nonpolluting space, global satellite communications system built using small (mini-, nano-, pico-) satellites.

Methods. The theoretical approach is proposed that allows constructing the orbits of mini-nano- and picosatellites based on the use of the national design groundwork.

Results. The article developed a method for constructing ultra-low orbit clusters of nano-satellites (small satellites) to increase the efficiency of using aerospace systems when creating and maintaining the life cycle of ULO SCS.

Conclusions. The method of orbits arrangement by distributed satellites is described. The technological capabilities of Ukraine to implement the method using national aerospace systems are quantified. There is scientific, technical and technological groundwork in the field of AS in Ukraine - these are the "flying cosmodromes" of An-124-100 and An-225 airplanes.

Keywords: satellite; micro-satellite; nano-satellite; satellite communications; cluster satellite of navigation and communications; orbit arrangement.
\end{abstract}

\section{INTRODUCTION}

One of the main features by which modern satellite communication systems (SCS) are classified is the height of the orbit on which the spacecraft are located. Low orbital (altitude 700-2000 km) (LEO - Low Earth Orbit), medium orbital (altitude $10000 \mathrm{~km}$ ) (MEO Medium Earth Orbit), high orbital or geostationary (altitude $36000 \mathrm{~km}$ ) (GEO - Geostatic Earth Orbit) systems have circular orbits. This circumstance determines a certain stability of the characteristics of the radio lines, what we cannot say about highly elliptical orbits (HEO - Hilly Ellíptícal Orbít) SCS, in which the distance between the satellite and the Earth's surface var- ies from almost a thousand to several tens of thousands of kilometers. Therefore, to create SCS, systems with circular orbits are predominantly used.

If geostationary SCS has a higher stability of the signal level in the radio link, then with decreasing orbital height, this indicator deteriorates due to the increased influence of the Doppler effect. However, a significant distance to the geostationary orbit causes a large attenuation and signal delay. In addition, the geostationary orbit is already oversaturated and unable to provide coverage of the polar regions, therefore in the long term preference is given to low and medium orbital SCS. Today we are aware of several projects to build SCS. The most ambitious is the creation of the 
Starlink system by SpaceX. It is planned to launch 11927 satellites into orbits at 340,550 and $1150 \mathrm{~km}$ high by March 2027. The main purpose of the Starlink system is to provide access to the Internet. It is assumed that the user receiving terminals for fast switching between satellites will be equipped with a phased antenna grate. The overall dimensions and appearance of such devices is similar to a regular laptop, so using such a system to provide a telephone service to mobile subscribers is quite problematic [1].

However, the very idea of using a low-orbit grouping of small spacecraft to create SCS with the provision of telephony services to mobile users is very attractive, since it simplifies the procedure for updating the space segment, and also solves the problem of space debris.

\section{ANALYSIS OF THE RESEARCH AND PUBLICATIONS}

A striking example of a low-orbit SCS is the Iridium system, which consists of 75 satellites in six orbits, 20 base stations and 2 control and monitoring stations. This year Iridium Communications Inc has completed the upgrade of the orbital component of the Iridium system [2]. The Iridium NEXT satellites launched by the Falcon 9 launch vehicle have a weight of $860 \mathrm{~kg}$ and are located at an altitude of $780 \mathrm{~km}$. Their service life is in the range of 7 to 10 years, and the cost is 31000000 dollars [3]. The earth's surface is covered by the formation of 48 beams by each satellite, each beam providing maintenance for a territory with a diameter of $700 \mathrm{~km}$. At the current time, to prevent the mutual influence of the signals of adjacent beams, each Iridium NEXT on average uses only 32 beams, which in general ensures the simultaneous creation of 3,840 telephone channels $[2,4]$.

The system Iridium provides 66 devices that are in active mode. One unit covers the territory with a diameter of 4000 $\mathrm{km}$. In the event of a breakdown or damage, the specified area cannot be fully serviced by adjacent devices. If there is a backup satellite, it takes some time to regroup the devices in orbit, so the standard quality of service will not be provided during this period. Conventional reservation, which provides for an increase in the number of satellites, may solve this problem, but this method is very expensive. Therefore, the idea arises of using a distributed apparatus in a certain sense, the failure of elements of which will insignificantly affect on functionality as a whole. Such an idea can be realized with the use of super-small space vehicles - nanosatellites (NS).

\section{STATEMENT}

Feasibility Reasoning. It is assumed that tasks that are performed by a single Iridium NEXT can be implemented by creating a group consisting of a certain number of NSs that form a cluster (Fig. 1).

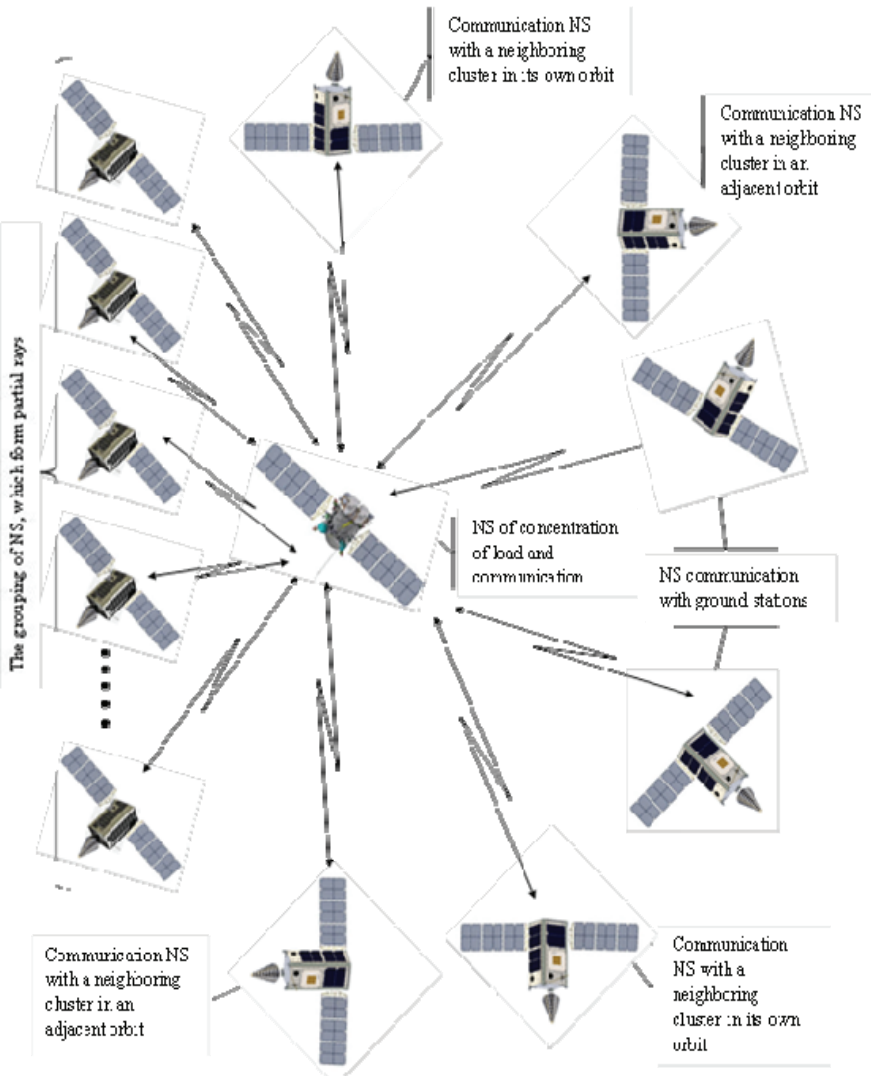

Fig. 1. Nano-satellite cluster

To create a cluster, 32 NS will be needed, each of which will form one beam to serve a zone with a diameter of $700 \mathrm{~km}$. $4 \mathrm{NS}$ is enough for interaction with other clusters in its own and adjacent orbits, 2 NS is enough for transmitting signals in the direction of ground stations, another $1 \mathrm{NS}$ is necessary to ensure interaction and control of these NS, it is advisable to duplicate it. Then the total number of NS clusters is 40 [5]. In general, the formation of directional beams instead of the usual phased antenna grate or parabolic antennas, which have large dimensions and mass, can be carried out using a helical conical antenna.

Width of directional patterns for forming the corresponding maintenance zones 32 NS that performs this function must be in the range $\theta=30-50^{\circ}$. For communication with subscriber terminals, the $1.6 \mathrm{GHz}$ range is allocated, so the antenna length will be $l=21-56 \mathrm{~cm}$ with a spiral diameter $d=6 \mathrm{~cm}$. Depending on the width of the diagram, the antenna gain $G=11-15 \mathrm{~dB}$ will be provided. The advantage of this design solution is that when antenna is folded, it will take no more than $V=30 \mathrm{~cm}^{3}$, that is, $3 \%$ of the total NS of the CubeSat-1 format [6].

Providing a managed mutual location of NS, including changing the direction of the beams that form the service areas, is possible with the use of active methods 
of orientation and stabilization, namely: a system on flywheel engines, a system with torque magnetic, and using jet engines. It should be noted that in recent times, conventional jet engines, due to significant fuel consumption, are replaced by ionic engines. Despite their relatively small thrust, there are prototypes with dimensions of 10x10x2 mm, developed directly for NS [7].

Provided that such systems have similar indicators of energy consumption, weight and dimensions, their ability to perform orientation and stabilization over a short time interval virtually coincide (Fig. 2).

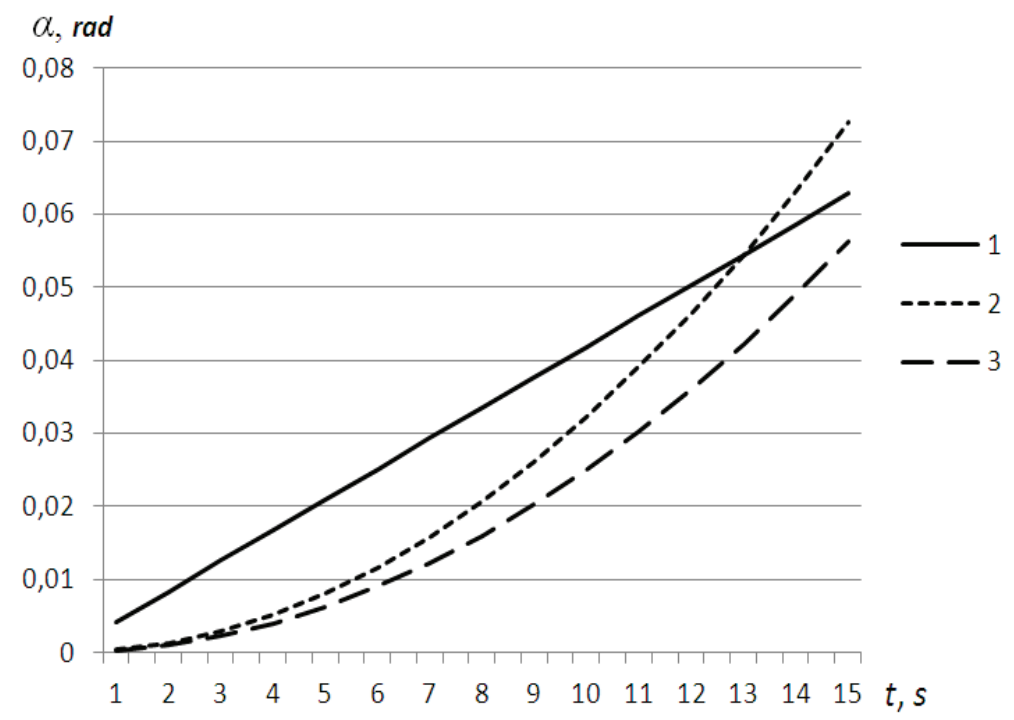

Fig. 2. Changing the angle of rotation NS for the system: 1 - on flywheel engines, 2 - with torque magnetic, 3 - with an ion engine

Since only ion engines can provide a change in the position of NS in orbit, their presence in the NS design is considered mandatory.

Limited resource fuel ion engines can be extended by the system on the engine-flywheel or a system with torque magnetic.

Thus, the orientation and stabilization system should be combined, that is, it should include ion engines and another of the above-mentioned systems. On average, such a system consumes about 4-8 Wt [8].

The maximum distance to the subscriber terminal, which is located on the border of the cluster's service area, can reach $1500 \mathrm{~km}$, which corresponds to a signal attenuation of almost $160 \mathrm{~dB}$.

If we take into account the power losses caused by circular polarization of the signal, which is formed by a spiral antenna, and losses in the atmosphere, caused by precipitation and various irregularities, to ensure a stable reception for a receiver with a sensitivity of $118 \mathrm{~dB}$, the signal level of the NS transmitter, which has an antenna with amplification $15 \mathrm{~dB}$, must be at least $36 \mathrm{~dB}$. Since the efficiency of the transmitter has an average value of $30 \%$, it is necessary to provide about $14 \mathrm{~W}$ of power for it, and $5 \mathrm{~W}$ for the receiver to work.
When NS is in the shadow of the Earth, its operation is provided by a battery that also needs power, therefore, the total power of the solar battery must be at least $45 \mathrm{~W}$ [9]. The conversion efficiency of solar radiation with modern batteries is in the range of $20-35 \%$ [10], therefore the surface area of the solar battery must be at least $0.165 \mathrm{~m} 2$, that is, for standard CubeSat sizes, consist of two symmetric surfaces with dimensions of $10 \times 90 \mathrm{~cm}$.

Obviously, to accommodate the elements of the orientation and stabilization system, electrical equipment, receiving and transmitting equipment and other functional elements inside NS, the NS design should be in CubeSat-2 format.

Mass production of the described NS format $\mathrm{Cu}-$ beSat- 2 can provide the cost of one unit with a weight of about $9 \mathrm{~kg}$ to 150 thousand dollars. Then the cost of the cluster will not exceed \$ 6 million.

When NS clusters are placed into orbit by the Falcon 9 booster rocket, which provides the cost of one $\mathrm{kg}$ of the payload of 11630 dollars [11], the proposed SCS can be compared with the Iridium system in terms of efficiency, which is determined by the ratio of the cost 
of the spacecraft (NS cluster) to the device (cluster NS). The results of this comparison are presented in Table 1.

Table 1. Satellite Performance Indicators

\begin{tabular}{|c|c|c|c|c|c|}
\hline $\begin{array}{c}\text { Orbit type of satellite sys- } \\
\text { tem (type of apparatus) }\end{array}$ & $\begin{array}{c}\text { Satellite } \\
\text { weight, } \\
\mathrm{kg}\end{array}$ & $\begin{array}{c}\text { The cost of one } \\
\text { apparatus, thou- } \\
\text { sand } \$\end{array}$ & $\begin{array}{c}\text { Number of channels } \\
\text { (connections) per } \\
\text { satellite }\end{array}$ & $\begin{array}{c}\text { Conditional } \\
\text { cost of the } \\
\text { channel, } \$\end{array}$ & $\begin{array}{c}\text { The cost of the channel, } \\
\text { taking into account the } \\
\text { launch into orbit, } \$\end{array}$ \\
\hline $\begin{array}{c}\text { Low orbital } \\
\text { (Iridium NEXT) }\end{array}$ & 860 & 31000 & 3840 & 8073 & 10677 \\
\hline $\begin{array}{c}\text { Low orbital } \\
\text { (CubeSat-2) }\end{array}$ & 9 & 150 & 120 & 1563 & 2653 \\
\hline
\end{tabular}

The cost of creating a national satellite communication system (SCS) can be reduced by: improving the system of creating an ultra-low orbit group of small satellites; support its reliable operation (replenishment with redundant units, repair of failed satellites or replacement of equipment in orbit and removal from orbit to restore operability under ground conditions); disposal of used units after return to Earth or destruction (burning) in dense atmospheric layers (forced change of the orbit or due to natural braking).

The most promising for creating and maintaining the functioning of ultra-low orbit (with a flight height above the Earth's surface from $200 \mathrm{~km}$ to $300 \mathrm{~km}$, i.e. significantly lower than the flight altitude of near-Earth inhabited space stations) communication systems that use clusters of micro-, nano-, pico-satellites (distributed satellites, i.e., built using small satellite groups) are aerospace systems.

These are systems with so-called "air launch", such as the one that uses the Boeing 747-400 as a launching platform and has been successfully tested by Virgin Orbit [12].

In Ukraine, there are different design and development plans for the aerospace systems, which are based on the An-124-100 Ruslan and An-225 Mriya aircraft $[13,14]$. To increase the efficiency of using these aerospace systems when creating and maintaining the life cycle of ultra-low orbit SCS, it is necessary to develop a method for constructing ultra-low orbit clusters of nanosatellites (small satellites).

\section{THE METHOD OF DESIGNING ULTRA-LOW ORBIT CLUSTERS OF NANOSATELLITES}

Problem statement. The effective use of the ultralow orbit satellite communication system throughout entire life cycle (building, maintaining functioning with the required quality, disposal) is determined significantly by the technological capabilities to form and maintain the hardware and structure of a cluster of small satellites (distributed satellite), i.e. controlling the process of its orbital packaging and rearrangement.
An aerospace systems with an arbitrary package of stages (multi-used and single-used, of aircraft- and rocket- type), transporting a carrier aircraft ("flying platform") to the launch point, are considered as a technical tool for assembling and rearrangement the distributed satellite's orbit.

A method is proposed that makes it possible to optimally use the properties of the aerospace systems to solve the problem of effective controlling the process of orbital packaging and rearrangement of distributed satellites.

This method is based on the theory of optimal control of compound dynamic systems (CDS), which move along branching paths [15-18].

The method of optimal packaging and rearrangement of the distributed satellite's orbit, proposed in the article, makes it possible to find the optimal trajectories of motion of all aerospace system stages in terms of energy consumption and accuracy.

Consider, as an example, the problem of optimizing the branching trajectory of the aerospace system of presumptive composition and packaging of stages. Suppose that an aerospace system consists of a carrier aircraft, two multi-used accelerators, and an aerospace aircraft with a multi-used external fuel tank.

Two tasks are required: the first is to replace used nanosatellites with new ones; the second task is to transfer the nanosatellites taken from orbit onto a trajectory that will ensure their disposal in dense atmospheric layers as a result of combustion. We perform the optimal design of the branching trajectory of the aerospace system as a ranching path of the motion of a compound dynamic system (CDS) [15]. The CDS motion scheme is shown in Fig. 3. 


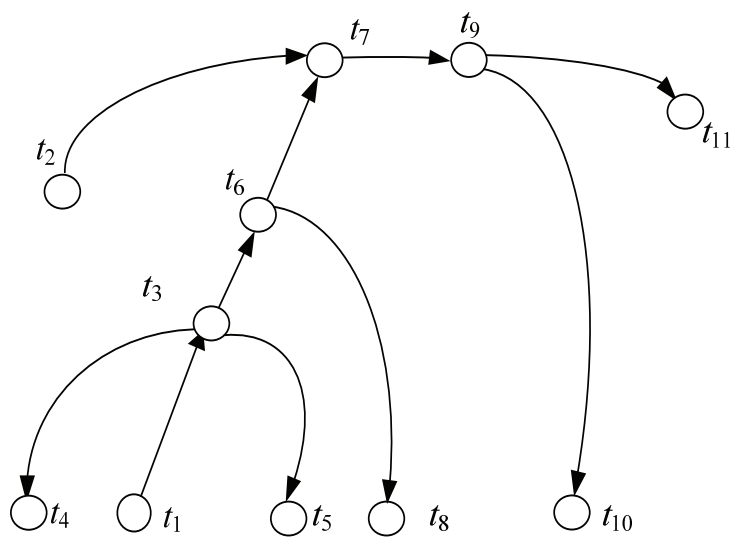

Fig. 3. An example of a branching path scheme for the CDS consisting of an aerospace system and distributed satellite (satellite + aerospace system)

Let us explain the notation used in Fig. 3: $t_{1}$ - the time of the start of insertion ("zoom" maneuver - going out to zero overload); $\left[t_{1} ; t_{3}\right]$ - the time interval of the aerospace system movement to the time $t_{3}$ - separation from the accelerator carrier aircraft and the aerospace aircraft (AA) with an external fuel tank; $t_{0}, t_{4}, t_{5}$ - time moments of the accelerators and fuel tank finish; $\left[t_{3} ; t_{6}\right]$, $\left[t_{6} ; t_{7}\right]$-time intervals of the movement of AA together with the external fuel tank and the AA after separation from the external fuel tank; $t_{2}$ - the time point from which it is advisable to consider a distributed satellite as an element of CDS - distributed satellite + aerospace system; $t_{10}, t_{11}-$ moments of time for completion of consideration of the motion of AA and distributed satellite, as elements of CDS - distributed satellite + aerospace system; $\left[t_{7} ; t_{9}\right]$ - the time interval of AA movement coupled with the distributed satellite (in this interval, the used nanosatellites are replaced with new ones).

The CDS path shown in Fig. 3. is referred to the class of branching trajectories [15-18]. The intention in this chapter is to present the method of designing the optimal branching trajectory of the aerospace system and distributed satellite, which together constitute a CDS. The method allows us to formulate in terms of the Pontryagin maximum principle (Macshane's minimum principle) the optimality conditions for the branching trajectory of CDS with an arbitrary branching scheme.

\section{Method of PAth Designing}

In solving the problems of designing the optimal orbits of distributed satellites, various types of aerospace systems and distributed satellites can be used.
This means that the corresponding CDS will move along various branching paths. These trajectories may have a branching scheme, which differs from the scheme shown in the example. At present, the optimality conditions have been formulated for particular schemes of branching trajectories, which requires a complete solution of the problem whenever a new branching path does not coincide with known particular cases $[3,4]$. This article describes the method of designing the branching trajectories for an arbitrary branching scheme (Fig. 4).

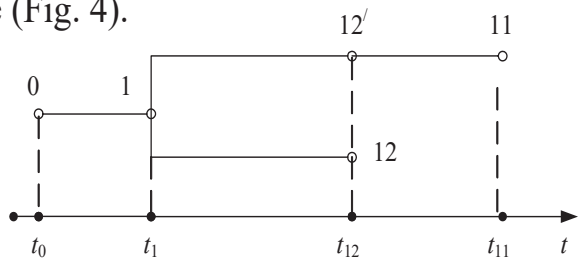

a)

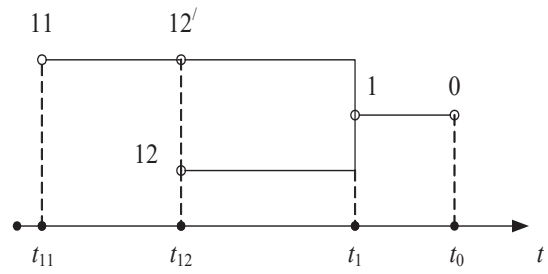

b)

Fig. 4. The time diagrams of elementary branching paths: $a-$ scheme with separation of subsystems; $b$ - scheme with grouping of subsystems.

Before proceeding to generalized formulations, we consider examples of the simplest branching trajectories, which allow us to substantiate the required generalizations (Fig. 4).

The equations describing the CDS motion with separation (Fig. 4, a) are as follows:

$$
\begin{gathered}
\dot{x}_{1}=f_{1}\left(x_{1}, u_{1}\right), \quad t \in\left[t_{0}, t_{1}\right], \\
\dot{x}_{11}=\left\{\begin{array}{l}
f_{11}^{12}\left(x_{11}, u_{11} ; x_{12}, u_{12}\right), \quad t \in\left[t_{1}, t_{12}\right], \\
f_{11}\left(x_{11}, u_{11}\right), \quad t \in\left[t_{12}, t_{11}\right],
\end{array}\right. \\
\dot{x}_{12}=f_{12}^{11}\left(x_{12}, u_{12} ; x_{11}, u_{11}\right), \quad t \in\left[t_{1}, t_{12}\right],
\end{gathered}
$$

where $x_{p}(t) \in R^{n}, u_{p} \in R^{m p}, u_{p} \in \Omega_{p}, p$-quantity of subsystems $(1,11,12)$.

The vector criterion for the quality of CDS functioning can be written in the additive form 


$$
\begin{aligned}
& I=S\left(x_{1}\left(t_{0}\right), t_{0} ; x_{1}\left(t_{1}\right), t_{1} ; x_{12}\left(t_{12}\right), t_{12} ; x_{11}\left(t_{11}\right), t_{11}\right)+ \\
& +I_{1}+I_{11}+I_{12},
\end{aligned}
$$

where

$$
\begin{aligned}
& I_{12}=\int_{t_{1}}^{t_{12}} \Phi_{12}\left(x_{12}, u_{12} ; x_{11}, u_{11}\right) d t \\
& I_{11}=\int_{t_{1}}^{t_{12}} \Phi_{11}^{12}\left(x_{12}, u_{12} ; x_{11}, u_{11}\right) d t+\int_{t_{12}}^{t_{11}} \Phi_{11}\left(x_{11}, u_{11}\right) d t .
\end{aligned}
$$

The optimality criterion corresponds to Bolze's form, where the function $S(\cdot)$ physically reflects the requirements for the values of coordinates of the CDS elements motion at the moments of start and end, as well as for the values of time moments. The integral terms of criterion show the requirements for character of the motion of CDS elements along corresponding path branches. The mutual influence of elements within the time interval $\left[t_{1}, t_{12}\right]$ is described as in the equations of its motion (2), (3) as well in particular integral criteria $I_{11}$ and $I_{12}$. The equations describing the motion of elements and the criterion in the scheme with grouping (Fig. 4, b) have the same form as ones for the scheme with separation, differing only in the sign of the time variation.

It is necessary to choose the controls $u_{1}(t) t \in\left[t_{0}, t_{1}\right], \quad u_{11}(t) t \in\left[t_{1}, t_{11}\right], u_{12}(t) t \in\left[t_{1}, t_{12}\right]$, vectors of phase coordinates $x_{1}\left(t_{0}\right), x_{1}\left(t_{1}\right), x_{11}\left(t_{12}\right)$, $x_{12}\left(t_{12}\right), x_{11}\left(t_{11}\right)$ and time points $t_{0}, t_{1}, t_{11}, t_{12}$ for both branching schemes (Fig. 4, $a, b$ ), so that the functional $I$ takes the smallest possible value. We formulate the necessary conditions for the optimality of branching path along which the CDS moves (Fig. 4, $a, b)$ [5].

Let $\quad x_{1}(t), u_{1}(t) t \in\left[t_{0}, t_{1}\right] ; \quad x_{11}(t), u_{11}(t), x_{12}(t)$; $u_{12}(t) t \in\left[t_{1}, t_{12}\right] ; \quad x_{11}(t), u_{11}(t) t \in\left[t_{12}, t_{11}\right]-$ allowable processes. For the optimality of processes, solutions must exist $\quad \lambda_{1}(t) t \in\left[t_{0}, t_{1}\right], \quad \lambda_{11}^{12}(t), \quad \lambda_{12}(t)$ $t \in\left[t_{1}, t_{12}\right], \lambda_{11}(t) t \in\left[t_{12}, t_{11}\right]$ for the adjoint vector equations

$$
\begin{aligned}
& \dot{\lambda}_{1}+\frac{\partial H_{1}}{\partial x_{1}}=0, \dot{\lambda}_{11}^{12}+\frac{\partial H_{11}^{12}}{\partial x_{11}}+\frac{\partial H_{12}}{\partial x_{11}}=0, \text { (5) } \\
& \dot{\lambda}_{12}+\frac{\partial H_{11}^{12}}{\partial x_{12}}+\frac{\partial H_{12}}{\partial x_{12}}=0, \dot{\lambda}_{11}+\frac{\partial H_{11}}{\partial x_{11}}=0, \text { (6) }
\end{aligned}
$$

such that the conditions are valid:
1) transversality for complementary functions and Hamiltonians

$$
\begin{gathered}
\left.\frac{\partial S}{\partial x_{1}\left(t_{0}\right)}\right|_{\wedge}-(-1)^{\beta} \lambda_{1}\left(\hat{t}_{0}\right)=0 ;\left.\frac{\partial S}{\partial t_{0}}\right|_{\wedge}+\left.(-1)^{\beta} H_{1}\right|_{\wedge}=0,(7) \\
\left.\frac{\partial S}{\partial x_{1 i}\left(t_{1 i}\right)}\right|_{\wedge}+(-1)^{\beta} \lambda_{1 i}\left(\hat{t}_{1 i}\right)=0 ;\left.\frac{\partial S}{\partial t_{11}}\right|_{\curlywedge}-\left.(-1)^{\beta} H_{11}\right|_{\wedge}=0,
\end{gathered}
$$

2) jump for complementary functions and Hamiltonians

$$
\begin{array}{r}
\left.\frac{\partial S}{\partial x_{1}\left(t_{1}\right)}\right|_{\wedge}+(-1)^{\beta}\left[\lambda_{1}\left(\hat{t}_{1}\right)-\lambda_{11}^{12}\left(\hat{t}_{1}\right)-\lambda_{12}\left(\hat{t}_{1}\right)\right]=0, \\
\left.\frac{\partial S}{\partial t_{1}}\right|_{\wedge}-(-1)^{\beta}\left[\left.H_{1}\right|_{\wedge}-\left.H_{11}^{12}\right|_{\wedge}-\left.H_{12}\right|_{\wedge}\right]=0, \\
\left.\frac{\partial S}{\partial x_{11}\left(t_{12}\right)}\right|_{\wedge}+(-1)^{\beta}\left[\lambda_{11}^{12}\left(\hat{t}_{12}\right)-\lambda_{11}\left(\hat{t}_{12}\right)\right]=0, \\
\left.\frac{\partial S}{\partial t_{12}}\right|_{\wedge}-(-1)^{\beta}\left[\left.H_{11}^{12}\right|_{\wedge}+\left.H_{12}\right|_{\wedge}-\left.H_{11}\right|_{\wedge}\right]=0,
\end{array}
$$

3) minimum of the Hamiltonians at the time $t \in\left[t_{q}, t_{p}\right]$ for control $u_{p}(t) \in \Omega_{p}$

$$
\left.H_{p}\right|_{\wedge}=\left.\min H_{p}\right|_{\wedge, u_{p}(t)}
$$

where $p$ - quantity of subsystems, $q$ - indices of sections of the branching path $(p=1, q=0 ; p=11, q=12)$,

4) minimum of the linear combination of Hamiltonians at time instants $t \in\left[t_{1}, t_{12}\right]$ for control $u_{p}(t) \in \Omega_{p}(p=11, q=12)$

$$
\left.H_{11}^{12}\right|_{\wedge}+\left.H_{12}\right|_{\wedge}=\min \left[\left.H_{11}^{12}\right|_{\wedge, u_{11}(t), u_{12}(t)}+\left.H_{12}\right|_{\wedge, u_{12}(t)}\right] .
$$

Herein icon «^» notes the optimal variables and parameters; symbol $\left.\right|_{\wedge, \xi}$ means that the expression should be calculated for the optimal values of variables and parameters, except for $\xi$; parameter $\beta$ takes the value $=1$ or 2 , for the related scheme with separation or grouping; $\quad H_{p}(\cdot)=\Phi_{p}(\cdot)+\lambda_{p}^{T} f_{p}(\cdot) \quad(p=1,11,12)$, $H_{11}^{12}(\cdot)=\Phi_{11}^{12}(\cdot)+{ }_{11}^{12} \lambda^{T} f_{11}^{12}(\cdot)$.

On the basis of stated above conditions (5) - (14) and considering a complex branching path as a package of simple ones, we formulate the following method for modeling the optimal branching path of the CDS with an arbitrary branching scheme. 
For the optimality of a branching path with an arbitrary branching scheme, existence of solutions of adjoint vector equations in the intervals of time between $t_{N}$-start of the motion, $t_{R}$-separation, $t_{G}$ - groupings, $t_{K}$-end of motion of compound elements, is required.

$$
\dot{\lambda}_{L}+\frac{\partial H_{L}}{\partial x_{L}}+\sum_{q}^{M} \frac{\partial H_{q}}{\partial x_{L}}=0
$$

where $L-$ index of section of the branching path; $M-$ quantity, $q$ - indices of sections of the branching path whose partial Hamiltonians depend on the phase coordinates of $L$-section so that the following conditions are valid:

1) transversality at time instants $\hat{t}_{N}=\hat{\tau}_{1}$ and $\hat{\imath} \wedge$

$$
\begin{array}{r}
\left.\frac{\partial S}{\partial x_{L}\left(\tau_{i}\right)}\right|_{\wedge}-(-1)^{i} \lambda_{L}\left(\tau_{i}\right)=0,(i=1,2),(16) \\
\left.\frac{\partial S}{\partial \tau_{i}}\right|_{\wedge}+\left.(-1)^{i} H_{L}\right|_{\wedge}+\sum_{v}^{p}\left(\left.H_{v}\right|_{\wedge, \hat{\tau}_{i-0}}-\left.H_{v}\right|_{\wedge, \hat{\tau}_{i+0}}\right)=0,
\end{array}
$$

where $p$ - quantity of subsystems whose motion is affected by start or end of the motion of subsystem along the $L$-section; $v$ - indices of the sections of branching path along which these subsystems move;

2) jump at instants $\hat{t}_{R}=\hat{\tau}_{1}$ and $\hat{t}_{G}=\hat{\tau}_{2} \hat{t}_{G}=\hat{\tau}_{2}$, related with division of the subsystem moving along the $L$-section, by $r$-subsystems or grouping $r$-subsystems into the subsystem moving along the $L$-section of the branching path

$$
\begin{gathered}
\left.\frac{\partial S}{\partial_{j} x_{L}\left(\tau_{i}\right)}\right|_{\wedge}+(-1)^{i}{ }_{j} \lambda_{L}\left(\hat{\tau}_{i}\right)-(-1)^{i} \sum_{q}^{r}{ }_{j} \lambda_{q}\left(\hat{\tau}_{i}\right)=0, \\
\left.\frac{\partial S}{\partial_{n} x_{L}\left(\tau_{i}\right)}\right|_{\wedge}+(-1)^{i}{ }_{n} \lambda_{L}\left(\hat{\tau}_{i}\right)-(-1)^{i} \sum_{q}^{r} \xi_{q}{ }_{n} \lambda_{q}\left(\hat{\tau}_{i}\right)=0, \\
(j=\overline{1, n-1 ;} i=1,2), \xi_{q} \geq 0, \sum_{q}^{r} \xi_{q}=1, \\
\left.\frac{\partial S}{\partial \tau_{i}}\right|_{\wedge}-\left.(-1)^{i} H_{L}\right|_{\wedge}+\left.(-1)^{i} \sum_{q}^{r} H_{q}\right|_{\wedge}+ \\
+\sum_{v}^{p}\left(\left.H_{v}\right|_{\wedge, \hat{\tau}_{i-0}}-\left.H_{v}\right|_{\wedge, \hat{\tau}_{i+0}}\right)=0,
\end{gathered}
$$

where $q$ - indices of sections of the branching path along which the subsystems move after separation or before grouping; $p$-quantity of subsystems, $v$-indices of sections of the branching path, along which these subsystems move, not participating in the points of time $t_{R}$ and $t_{G}$ in division or grouping, but the motion of which is affected by the separation or grouping of subsystems moving along sections with indices $L$ and $q$; ${ }_{n} x_{L}(t)$ - phase coordinate describing mass change; jump condition on the $\mu$-section of branching path at time $\hat{t}_{S}$, coinciding with one of the instants associated with structural changes in the CDS caused by start or end of the motion, separation or grouping of subsystems not related to $\mu$-section, but influencing it

$$
\left.\frac{\partial S}{\partial x_{\mu}\left(t_{s}\right)}\right|_{\wedge}-\lambda_{\mu}\left(\hat{t}_{S}-0\right)+\lambda_{\mu}\left(\hat{t}_{S}+0\right)=0 ;
$$

3) minimum of the linear combination of Hamiltonians at the instants between the moments $\hat{t}_{N}$, $\hat{t_{R}, \hat{t}_{G}, \hat{t}_{K}}$

$$
\left.\sum_{q}^{\Lambda} H_{q}\right|_{\wedge}=\left.\min _{u_{q} \in \Omega_{q}} \sum_{q}^{\Lambda} H_{q}\right|_{\curlywedge, u_{q}}
$$

where $\Lambda$ - number of subsystems with interacting controls within specified time intervals; $q$-indices of the sections of branching path along which these subsystems move.

The stated method is the methodological basis for constructing computing algorithms that allow modeling the optimal paths of the CDS motion. The method for modeling optimal branching paths is a part of the software of CDS computer-aided design system. Consider an example illustrating use of the simulation method for the optimal branching path. According to the specified scheme of branching path (Fig. 3), its time diagram is drawn up (Fig. 5), in which the time instants of structural transformations in the CDS motion pattern with indication its membership to the corresponding types of time moments are arranged chronologically: $\hat{t}_{N}$, $\wedge \wedge \hat{\imath}$ 


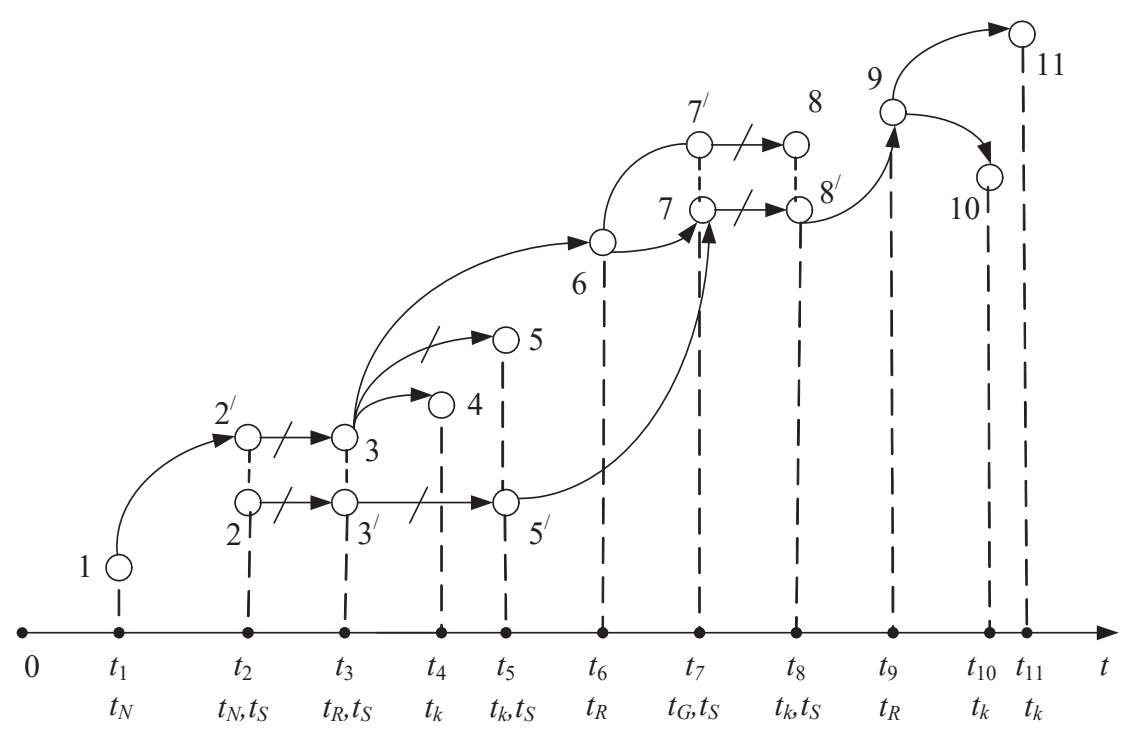

Fig. 5. Time diagram of the branching path

The path sections, moving along which the CDS elements interact each with other, are marked with a line. The optimality criterion is written in the form consisting of the terminal part $S(\cdot)$, dependent on the coordinates of elements at time instants $t_{i}(i=\overline{1,11})$ and these moments of time, as well as the sum of particular integral criteria

$I_{i}=\int_{t_{a}}^{t_{b}} \Phi_{i}(\cdot) d t \quad(i=\overline{1,11}), \quad(a \neq b),(a=\overline{1,11})$,

$(b=\overline{1,11})$, recorded for the each section of branching path (Fig. 4), enclosed between neighboring points located on it.

The motion of elements along the path is defined by equations of $\dot{x}=f(\cdot)$ type, where $f(\cdot)$ - function that depends on the controls and coordinates of the subsystem, as well as on the controls and coordinates of the interacting subsystem, if the branch section is marked with a line. Applying the procedure formulated below, we obtain condition - for the optimality of path (Fig. 4) it is necessary to have solutions of adjoint vector equations of type (15) such there conditions of type (16-21) are valid.

To solve finally the task of modeling the optimal branching path, it is necessary to add the listed differential equations and algebraic conditions with the differential equations of motion of the subsystems along the path branches. Note that the sequence of time instants $t_{1}<t_{2}<\ldots<t_{10}<t_{11}$ in the task with free time is given from physical considerations and is approximate. If it is disturbed, as a result of solution of the task, and the change in the sequence of branches of the path is permissible by the physical meaning of the task, then repeating all calculations for new refined sequence of time instants is required. The information given in Tables $2-4$ is initial data that allows using standard subprograms for solving ordinary differential and algebraic equations, and thereby complete practically solution the CDS optimal path modeling task.

Table 2. Conditions for formulation of equations for conjugate variables.

\begin{tabular}{|c|c|c|c|c|c|c|c|c|}
\hline \multirow{2}{*}{$\begin{array}{c}\text { Type of } \\
\text { equation }\end{array}$} & \multicolumn{10}{|c|}{ Legend of branch, $L$} \\
\cline { 2 - 8 } & $1 ; 2$ & $2 ; 3$ & $2 ; 3$ & $3 ; 4$ & $3 ; 6$ & $3 ; 5$ & $3 ; 5^{\prime}$ & $5 ; 7$ \\
\hline$(15)$ & $M=0$ & $M=1$ & $M=1$ & $M=0$ & $M=0$ & $M=1$ & $M=1$ & $M=0$ \\
& - & $q=\left(2 ; 3^{\prime}\right)$ & $q=(2 ; 3)$ & - & - & $q=(2 ; 5)$ & $q=(3 ; 5)$ & - \\
\hline
\end{tabular}

Table 2 cont'd.

\begin{tabular}{|c|r|r|r|r|r|r|r|}
\hline \multirow{2}{*}{$\begin{array}{c}\text { Type of } \\
\text { equation }\end{array}$} & \multicolumn{7}{|c|}{ Legend of branch, $L$} \\
\cline { 2 - 8 } & $6 ; 7$ & $6 ; 7$ & $7 ; 8$ & $7 ; 8$ & $8 ; 9$ & $9 ; 10$ & $9 ; 11$ \\
\hline \multirow{2}{*}{$(15)$} & $M=0$ & $M=0$ & $M=1$ & $M=1$ & $M=0$ & $M=0$ & $M=0$ \\
& - & - & $q=(7 ; 8)$ & $q=(7 ; 8)$ & - & - & - \\
\hline
\end{tabular}

Table 3. The solutions of differential equations for conjugate variables must meet the following conditions. 


\begin{tabular}{|c|c|c|c|c|c|c|}
\hline $\begin{array}{c}\text { Condition } \\
\text { type }\end{array}$ & $t_{1}$ & $t_{2}$ & $t_{3}$ & $t_{4}$ & $t_{5}$ & $t_{6}$ \\
\hline (16) & $\begin{array}{c}L=(1 ; 2) ; \\
i=1\end{array}$ & $\begin{array}{c}L=(2 ; 3) ; \\
i=1\end{array}$ & - & $\begin{array}{r}L=(3 ; 4) ; \\
i=2\end{array}$ & $\begin{array}{r}L=(3 ; 5) ; \\
i=2\end{array}$ & - \\
\hline (17) & $\begin{array}{l}L=(1 ; 2) ; \\
i=1 ; p=0\end{array}$ & $\begin{array}{c}L=(2 ; 3) ; \\
i=1 ; p=1 ; \\
v=(1 ; 2 ; 3)\end{array}$ & - & $\begin{array}{c}L=(3 ; 4) ; \\
\dot{E}=2 ; p=0\end{array}$ & $\begin{array}{l}L=(3 ; 5) ; \\
i=2 ; p=1 ; \\
v=(3 ; 5 ; 7)\end{array}$ & - \\
\hline (18) & - & - & $\begin{array}{c}L=(2 ; 3) ; \\
i=1 ; \\
r=3 ; q=(3 ; 1), \\
(3 ; 5),(3 ; 4)\end{array}$ & - & - & $\begin{array}{c}L=(3 ; 6) ; \\
i=2 ; r=2 ; \\
q=(6 ; 7), \\
(6 ; 7)\end{array}$ \\
\hline (19) & - & - & $\begin{array}{c}L=(2 ; 3) ; \\
i=1 ; r=3 ; p=1 ; \\
q=(3 ; 6), \\
(3 ; 5),(3 ; 4) ; \\
V=(2 ; 3 ; 5)\end{array}$ & - & - & $\begin{array}{c}L=(3 ; 6) ; \\
i=2 ; r=2 ; \\
q=(6 ; 7), \\
(6 ; 7)\end{array}$ \\
\hline (20) & - & $\mu=(1 ; 2 ; 3)$ & $\mu=(2 ; 3 ; 5)$ & - & $\mu=(3 ; 5 ; 7)$ & - \\
\hline
\end{tabular}

Table 3 cont'd.

\begin{tabular}{|c|c|c|c|c|c|}
\hline $\begin{array}{l}\text { Condition } \\
\text { type }\end{array}$ & $t_{7}$ & $t_{8}$ & $t_{9}$ & $t_{10}$ & $t_{11}$ \\
\hline (16) & - & $\begin{array}{c}L=(7 / 8) ; \\
i=2\end{array}$ & - & $\begin{array}{c}L=(9 ; 10) ; \\
i=2\end{array}$ & $\begin{array}{c}L=(9 ; 11) ; \\
i=2\end{array}$ \\
\hline (17) & - & $\begin{array}{c}L=(7 / 8) \\
p=1 ; \\
v=(7 ; 8 ; 9)\end{array}$ & - & $\begin{array}{c}L=(9 ; 10) ; \\
i=2\end{array}$ & $\begin{array}{c}L=(9 ; 11) ; \\
i=2\end{array}$ \\
\hline (18) & $\begin{array}{c}L=(7 ; 8) ; \\
i=2 ; r=2 ; \\
q=(6 ; 7),(5 ; 7)\end{array}$ & - & $\begin{array}{l}L=(8 ; 9) ; \\
i=2 ; r=2 ; \\
q=(9 ; 10), \\
(9 ; 11)\end{array}$ & - & - \\
\hline (19) & $\begin{array}{c}L=(7 ; 8) ; \\
i=2 ; r=2 ; p=1 ; \\
q=(6 ; 7),(5 ; 7) ; v=(6 ; 7 ; 8)\end{array}$ & - & $\begin{array}{c}L=(8 ; 9) \\
i=2 ; r=2 ; \\
p=0 ; \\
q=(9 ; 10) \\
(9 ; 11)\end{array}$ & - & - \\
\hline (20) & $\mu=\left(6 ; 7^{\prime ;} 8\right)$ & $\mu=\left(7 ; 8^{\prime ; 9}\right)$ & - & - & - \\
\hline
\end{tabular}

Table 4. Conditions for Hamiltonian minimizing.

\begin{tabular}{|c|c|c|c|c|c|c|}
\hline \multirow{2}{*}{ Equation } & \multicolumn{6}{|c|}{ Time space } \\
\cline { 2 - 7 } & $t_{1}-t_{2}$ & $t_{2}-t_{3}$ & $t_{3}-t_{4}$ & $t_{3}-t_{5}$ & $t_{3}-t_{6}$ & $t_{5}-t_{7}$ \\
\hline \multirow{2}{*}{$(21)$} & $\Lambda=1$ & $\Lambda=1$ & $\Lambda=1$ & $\Lambda=2$ & $\Lambda=1$ & $\Lambda=1$ \\
& $q=\left(1 ; 2^{\prime}\right)$ & $q=(2 ; 2),(2 ; 3)$ & $q=(3 ; 4)$ & $q=(3 ; 5),(3 / 5)$ & $q=(3 ; 6)$ & $q=(5 ; 7)$ \\
\hline
\end{tabular}

Table 4 cont'd.

\begin{tabular}{|c|c|c|c|c|c|c|}
\hline \multirow{2}{*}{ Equation } & \multicolumn{6}{|c|}{ Time space } \\
\cline { 2 - 7 } & $t_{6}-t_{7}$ & $t_{6}-t_{7}$ & $t_{7}-t_{8}$ & $t_{8}-t_{9}$ & $t_{9}-t_{10}$ & $t_{9}-t_{11}$ \\
\hline \multirow{2}{*}{$(21)$} & $\Lambda=1$ & $\Lambda=1$ & $\Lambda=2$ & $\Lambda=1$ & $\Lambda=1$ & $\Lambda=1$ \\
& $q=(6 ; 7)$ & $q=(6 ; 7)$ & $q=(7 ; 8),(7 ; 8)$ & $q=(8 ; 9)$ & $q=(9 ; 10)$ & $q=(9 ; 11)$ \\
\hline
\end{tabular}

The results of applying the above method for calculating the payload in the ultra-low orbit are presented in Table 5 The initial data for the calculations and mathe- matical models of motion of the aerospace system stages are described in [14, 15]. 
Table 5. Calculation results.

\begin{tabular}{|c|c|c|}
\hline Type of aerospace system & Carrier aircraft & $\begin{array}{l}\text { The results of calculating the total } \\
\text { mass of the cluster of small satel- } \\
\text { lites (payload) in a circular equato- } \\
\text { rial orbit at altitude of } 200 \mathrm{~km}\end{array}$ \\
\hline $\begin{array}{l}\text { Multi-use lightweight aero- } \\
\text { space system }\end{array}$ & $\begin{array}{l}\text { An-124-100 modified for mounting of unmanned } \\
\text { aerospace aircraft on a pylon under wing }\end{array}$ & $950 \mathrm{~kg}$ \\
\hline $\begin{array}{l}\text { Multi-use lightweight aero- } \\
\text { space system ORIL type }\end{array}$ & $\begin{array}{l}\text { An-124-100 modified for paradropping the carri- } \\
\text { er rocket located inside the fuselage }\end{array}$ & $1,050 \mathrm{~kg}$ \\
\hline $\begin{array}{l}\text { Multi-use middle aerospace } \\
\text { system of SVITYAZ type }\end{array}$ & $\begin{array}{l}\text { An- } 225 \text { modified for dropping a carrier rocket } \\
\text { placed on top of the fuselage, using the zoom } \\
\text { maneuver }\end{array}$ & $8,120 \mathrm{~kg}$ \\
\hline $\begin{array}{l}\text { Multi-use middle aerospace } \\
\text { system of MAKS type }\end{array}$ & $\begin{array}{l}\text { An-225 modified for dropping an unmanned } \\
\text { aerospace aircraft with fuel tank placed on top of } \\
\text { the fuselage, using the zoom maneuver }\end{array}$ & $6,500 \mathrm{~kg}$ \\
\hline $\begin{array}{l}\text { Multi-use middle aerospace } \\
\text { system of MAKS-T type }\end{array}$ & $\begin{array}{l}\text { An- } 225 \text { modified for dropping the rocket with a } \\
\text { fuel tank placed on top of the fuselage, using the } \\
\text { zoom maneuver }\end{array}$ & $16,800 \mathrm{~kg}$ \\
\hline $\begin{array}{l}\text { Multi-use middle aerospace } \\
\text { system of Interim HOTOL } \\
\text { International Aerospace Sys- } \\
\text { tem type }\end{array}$ & $\begin{array}{l}\text { An- } 225 \text { modified for dropping an unmanned } \\
\text { aerospace aircraft placed on top of the fuselage, } \\
\text { using the zoom maneuver }\end{array}$ & $9,050 \mathrm{~kg}$ \\
\hline $\begin{array}{l}\text { Multi-use heavy aerospace } \\
\text { system }\end{array}$ & $\begin{array}{l}\text { An-5XX two-fuselage biplane with ten engines, } \\
\text { built specifically for carrying and dropping from } \\
\text { the interfuselage of unmanned aerospace aircraft } \\
\text { using the zoom maneuver }\end{array}$ & $29,000 \mathrm{~kg}$ \\
\hline
\end{tabular}

\section{CONCLUSION}

Ultra-low-orbit SCS are communication systems with cluster (distributed) satellites that form a group (armada) of small, ultra-small, nano-, pico-satellites that move in orbits close to the dense layers of the Earth's atmosphere ("sliding" on the upper edge of the dense layer of the Earth's atmosphere - a "sliding" orbit).

The movement in such orbit of a small-sized vehicle (provided that the engine is not turned on) leads to its rapid deceleration and complete combustion in the Earth's atmosphere, i.e. complete clearing of the orbit without the formation of space debris.

The global problem for humanity is being solved: the creation of satellite communications technology that does not contaminate outer space.

The article substantiates the economic and technical feasibility and advisability of creating an ultra-low-orbit SCS: small satellites are much cheaper than large satellites placed in high orbits; the use of aerospace systems reduces the cost of insertion many small vehicles into ultra-low orbits, inspection their condition, repairing in orbit or removing from orbit, and returning to the Earth (all operations can be performed by unmanned vehicles and robots). Scientific, technical and technological groundwork in the field of aerospace systems is available in Ukraine: launching platforms based on An-124100 and An-225 aircraft.

To increase the efficiency of using these aerospace systems when creating and maintaining the life cycle of ultra-low orbit SCS, the method for constructing ultralow orbit clusters of nanosatellites (small satellites) was developed and described in the article. The article suggests the method for constructing a branching path of the aerospace system motion that is a compound dynamic system.

The method allows formulating the procedure for modeling the optimal branching path of the compound dynamic system with an arbitrary branching scheme in terms of the theory of optimal control.

The procedure is a part of the software of the aerospace system computer-aided design system and can be used to construct computing algorithms taking into account the specificity of information-telecommunication 
interaction of elements of specific compound dynamic systems.

In order to implement the CDS motion configuration along the obtained optimal branching path, we can use the technique of wide-sense robust control design [19], which is based on the general procedure of construction of Lyapunov functions through first integrals of differential equations [20].

\section{REFERENCES}

[1] Starlink, https://www.youtube.com/watch?v=ySCG2Z_ FsYQ/, last accessed 2019.

[2] Wind-sail, https://wind-sail.ru/equpment/svyaz/sistemamobilnoj-sputnikovoj-svjazi-iridium/, last accessed 2019.

[3] Vse sputniki svyazi, http://ecoruspace.me/, last accessed 2019.

[4] Satlink, http://www.satlink.ru/Spytnikovaia_sviaz/ Iridium Tehnicheskie harakteristiki/, last accessed 2019.

[5] Lysenko, O., Yavisya, V., Tureichuk, A., Alekseeva. I.: Monitoring system and fixed communication on the basis of nanosatellites. 5th International ScientificPractical Conference Problems of Infocommunications. Science and Technology, pp. 495-498. Kyiv, Ukraine (2018).

[6] Neganov, N., Klyuev, D., Tabakov, D.: Ustroystva SVCH i antenny. Teoriya i tekhnika antenn. Chast' 2, 728 p. Moscow, Yeditorial (2016).

[7] Hi-news.ru, http://hi-news.ru/science/izobreteny-mikrodvigatelidlya-nanosputnikov.html/, last accessed 2019.

[8] Yavisya, V., Bendasiuk, N.: Analysis of methods fo orientation and stabilization of nano-satellites. 4th International Conference Methods and Systems of Navigation and Motion Control, pp. 158-161. Kyiv, Ukraine (2016).

[9] B-eco, http://b-eco.ru/solar_panels, last accessed 2019.

[10] Solarb.ru, http://solarb.ru/solnechnye-batarei-vkosmicheskom-prostranstve/, last accessed 2019.

[11] Astronews, http://www.Astronews.Space/Spacecrafts2/252-Raschet-Stoimosti-Proizvodstva-ObsluzhivaniyaI-Zapuska-Raket-Falcon-9-I-Falcon-Heavy-KompaniiSpacex/, last accessed 2019.
[12] Virgin Orbit, https://uazmi.org/news/post ghvjbxmN6zT3F7w4QYohsU/, last accessed 2019.

[13] Lysenko, O., Chekanova, I., Gusynin, V, Serdyuk I., Zhukov V.: Podkhody $\mathrm{k}$ sozdaniyu natsional'noy aviatsionno-kosmicheskoy sistemy legkogo klassa. Adaptivnyye sistemy avtomaticheskogo upravleniya, №4(24), pp. 39-44. Kyiv, Ukraine (2002).

[14] Lysenko, O., Tachinina, O., Alekseeva, I.: Rozvytok metodu optymizatsiyi roz'haluzhenykh trayektoriy $u$ zadachakh rozrakhunku opornoho rukhu dvostupenevoho bezpilotnoho demonstratora hiperzvukovykh tekhnolohiy, № 1, pp. 101-108. Kyiv, Ukraine (2018).

[15] Lysenko, O., Tachinina, O.: Method of path constructing of information robot on the basis of unmanned aerial vehicle. Proceedings of the National Aviation University, № 4(73), pp. 60-68. Kyiv, Ukraine (2017).

[16] Lysenko, O., Tachinina, O., Alekseeva, I., Zacharchenko, V.: The optimal injection path of group of nanosatellite multisensor-based platforms. IEEE 4th International Conference «Methods and Systems of Navigation and Motion Control», pp. 155-158. Kyiv, Ukraine (2016).

[17] Lysenko, O., Tachinina, O., Alekseeva, I. :Path Constructing Method of Unmanned Aerial Vehicle. IEEE 4th International Conference, «Actual Problems of Unmanned Aerial Vehicles Developments», pp. 254-259. Kyiv, Ukraine (2017).

[18] Lysenko, O., Tachinina, O., Alekseeva, I.: Algorithm for operational optimizationof two-stage hypersonic unmanned aerial vehicle branching path. IEEE 5th International Conference «Methods and Systems of Navigation and Motion Control», pp. 11-15. Kyiv, Ukraine (2018).

[19] Sparavalo, M. Adequate mathematical modelling by wide-sense robust control design in a thrust-vectored flight dynamics problem. CEAS Aeronaut J 11, 289-301 (2020). https://doi.org/10.1007/s13272-019-00425-x

[20] Sparavalo, M. Lyapunov Functions in Nonlinear Unsteady Dynamics and Control: Poincaré's Approach from Metaphysical Theory to Down-to-Earth Practice. Ed.1. - LaVergne: Lightning Source Inc., 2016. - 104 p. 
Лисенко О.І., Спаравало М.К. Тачиніна О.М., Явіся В.С., Пономаренко С.О. Обгрунтування доцільності створення низькоорбітальних систем зв'язку на базі малих супутників i метод конструювання їх орбіт

Проблематика. Стаття присвячена обгрунтуванню підходу до вирішення глобальної проблеми для людства: створення технології супутникового зв'язку, яка не засмічує космос сміттям. Наднизькоорбітальні супутникові системи зв'язку - це системи зв'язку з кластерними (розподіленими) супутниками, які утворюють угруповання (армаду) малих, понад малих, нано-, піко- супутників, які переміщаються по орбітах близьким до щільних шарів атмосфери Землі ( «ковзаючи» по верхній кромці щільного шару атмосфери Землі - «змінна» орбіта). Рух по такій орбіті малогабаритного апарату (при умові не включення двигуна) призводить до його швидкого гальмування і повного згоряння в атмосфері Землі, тобто повне очищення орбіти без створення космічного сміття.

Мета досліджень. Обгрунтувати доцільність і можливість створення і підтримки функціонування економічно вигідної, не забруднюючої космос, глобальної системи супутникового зв'язку, побудованої з використанням малих (міні-, нано-, піко-) супутників.

Методика реалізації. Запропоновано теоретичний підхід, що дозволяє конструювати орбіти міні нано- та пікосупутників на основі використання національного науково-технічного доробку.

Результати досліджень. Для підвищення ефективності використання авіаційно-космічних систем при створенні $\mathrm{i}$ підтримці життєвого циклу наднизькоорбітальних супутникових систем зв'язку в статті розроблений метод конструювання наднизькоорбітальних кластерів наносупутників (малих супутників).

Висновки. Викладено метод компонування орбіт розподіленими супутниками. Кількісно оцінено технологічні можливості України по реалізації методу за допомогою національних авіаційно-космічних систем. В Україні є науковотехнічний і технологічний доробок в області авіаційно-космічних систем - це «літаючі космодроми» Ан-124-100 і Ан $-225$.

Ключові слова: супутник; мікросупутник; наносупутник; супутниковий зв'язок; кластерний супутник навігаціі і зв'язку; компоновка орбіт.

\section{Лысенко А.И., Спаравало М.К. Тачинина Е.Н., Явися В.С., Пономаренко С.А. Обоснование целесообразности создания сверхнизкоорбитальных систем связи на базе малых спутников и метод конструирования их орбит}

Проблематика. Статья посвящена обоснованию подхода к решению глобальной проблемы для человечества: созданию технологии спутниковой связи, которая не засоряет космос мусором. Сверхнизкоорбитальные спутниковые системы связи - это системы связи с кластерными (распределёнными) спутниками, которые образуют группировку (армаду) малых, сверх малых, нано-, пико- спутников , которые перемещаются по орбитам близким к плотным слоям атмосферы Земли («скользя» по верхней кромке плотного слоя атмосферы Земли - «скользящая» орбита). Движение по такой орбите малогабаритного аппарата (при условии не включения двигателя) приводит к его быстрому торможению и полному сгоранию в атмосфере Земли, т.е. полной очистке орбиты без образования космического мусора.

Цель исследований. Обосновать целесообразность и возможность создания и поддержания функционирования экономически выгодной, не загрязняющей космос, глобальной системы спутниковой связи, построенной с использованием малых (мини-, нано-, пико- ) спутников.

Методика реализации. Предложен теоретический подход, позволяющий конструировать орбиты мини- нано- и пикоспутников на основе использования национального научно-технического задела.

Результаты исследований. Для повышения эффективности использования авиационно-космических систем при создании и поддержании жизненного цикла сверхнизкоорбитальных спутниковых систем связи в статье разработан метод конструирования сверхнизкоорбитальных кластеров наноспутников (малых спутников).

Выводы. Изложен метод компоновки орбит распределенными спутниками. Количественно оценены технологические возможности Украины по реализации метода с помощью национальных авиационно-космических систем. В Украине имеется научно-технический и технологический задел в области АКС - это «летающие космодромы» Ан-124100 и Ан -225.

Ключевые слова: спутник; микроспутник, наноспутник; спутниковая связь; кластерный спутник навигации и связи; компоновка орбит. 